\title{
Strategic Environmental Assessment in Brazilian Academic Research
}

\author{
Amarilis Lucia Casteli Figueiredo Gallardo \\ Débora Mendonça Monteiro Machado \\ Cláudia Terezinha Kniess
}

${ }^{I}$ Universidade de São Paulo e Universidade Nove de Julho, São Paulo, SP, Brazil.

"I Universidade Nove de Julho, São Paulo, SP, Brazil.

III Universidade Federal de São Paulo, Universidade São Judas Tadeu e Universidade de Taubaté, São Paulo, SP, Brazil.

\begin{abstract}
The Strategic Environmental Assessment (SEA) is an instrument for integrating the environmental issue into strategic planning with increasing the emphasis on impact assessment research in the world. Although it is not mandatory in Brazil, there are applications and initiatives for its formalization. The objective is to explore the Brazilian academic research on SEA through quantitative and qualitative analysis of papers, theses, and dissertations. The results reveal that since 2000 to 2020 , local research has been represented by 75 dissertations and theses from 20 universities and, since 2005 to 2020, by 61 articles from 114 authors, published in 30 journals. While the research is in an early stage of development, it covers a broad diagnosis of the application of SEA, contributions to a Brazilian system, has little methodological discussion, and encompasses comprehensive analysis of the quality of the reports. We recommend that future research aims at fostering and building a legal framework for SEA for Brazilian planning.
\end{abstract}

Keywords: Strategic Environmental Assessment; Academic research; strategic sectoral and territorial planning; Brazil.

São Paulo. Vol. 24, 2021

Original Article

DOI: http://dx.doi.org/10.1590/1809-4422asoc20200022r3vu2021L5AO 


\section{Introduction}

The Strategic Environmental Assessment (SEA) is a planning instrument that factors the environmental issue into decision-making that precedes the level of engineering projects. Developed to assess potential environmental impacts of policies, plans, and programs (PPP) (WOOD; DJEDDOUR, 1989), the current view is that it can influence its formulation seeking to integrate the environmental variable into strategic planning (SÁNCHEZ, 2017).

From this perspective, there are several obvious benefits. SEA adds social participation (COSTA et al., 2009) and pluralism of views from different stakeholders (CAPE et al., 2018). SEA allows for the inclusion of themes on the global environmental agenda such as climate change and ecosystem services (LARSEN et al., 2013; GENELETTI, 2013), as well as promotes effectiveness, in its various dimensions, in decision-making processes (POPE et al., 2018). SEA has acted as a facilitator of Environmental Impact Assessment (EIA) processes (SÁNCHEZ; SILVA-SÁNCHEZ, 2008; PHYLIP-JONES; FISCHER, 2015) while contributing to environmental governance (MONTEIRO; PARTIDÁRIO, 2017) and sustainability (DÁVILA et al., 2019).

With systematic use in about 60 countries (TETLOW; HANUSCH, 2012), SEA is not mandatory in Brazil (SÁNCHEZ, 2017). In the state of São Paulo, in 1994 (SANTOS; SOUZA, 2011), the pioneering institutionalization initiative was followed by bills at the federal level that aimed to include SEA in the legal framework of the National Environmental Policy Act (NEPA), Federal Law no. 6,938 of 1981 (ZIONI; FREITAS, 2015; SÁNCHEZ, 2017). In São Paulo, there are guidelines for the use of SEA in decrees that provide for the State Policy on Climate Change (SPCC) (NADRUZ et al., 2018), the São Paulo Oil and Natural Gas Program, and the Master Plan Strategy of the Municipality of São Paulo (SIQUEIRA-GAY; SÁNCHEZ, 2019). In Minas Gerais, there are decrees that determine the use of the instrument in the development of sectoral public policies (CRESPO; RAIMUNDO, 2018).

In the efforts to create legal frameworks and disseminate research aimed at demonstrating the value of SEA within the framework of environmental policy and local development (MONTAÑO; SOUZA, 2015; MALVESTIO; MONTAÑO, 2019), according to Sánchez (2017), SEA implementation makes little progress and influences in decision-making processes in the country. Even so, Tshibangu and Montaño (2019) highlight that the 68 cases of SEA application in Brazilian planning have led to valuable lessons. For Pellin et al. (2011, p. 34), the consolidation of the instrument at the national level should be based on internal discussions and Brazilian institutional experiences.

In the international literature, SEA has been the object of increasing attention since the early 1990s (TETLOW; HANUSCH, 2012). A bibliometric analysis revealed SEA as the most important component of research with impact assessment (IA) instruments in the world over the last 20 years (LI; ZHAO, 2015). According to this survey, Brazil is among the countries with a high number of publications but mainly devoted to research with the project Environmental Impact Assessment (EIA). Caschili et al. (2014) conducted a quantitative analysis of the SEA bibliographic network from 7,662 publications 
to identify the topics of greatest impact and assess the different contexts of application.

In Brazil, Duarte, Dibo, and Sánchez (2017) performed a mapping of technicalscientific production on IA and environmental licensing to support eventual changes in the legal framework of EIA in the context of the NEPA, but it did not include the SEA.

Thus, the importance of the topic is reinforced worldwide, and the absence of articles that present a systematic literature review on SEA in Brazil is noted. The purpose of this article is to explore Brazilian academic research on Strategic Environmental Assessment. Thus, we expect this work to reveal an in-depth diagnosis of this research as well as reflections that can contribute to improving the current stage of application of the instrument, reveal research trends, and technically support a future legal framework.

\section{Method}

Brazilian academic research on SEA materializes in a variety of technical documents. A search on Google Scholar with the words SEA and Brazil yielded 2,390 results (01/08/2020).

For the content cut, we opted for epistemological knowledge to represent the current state of the art. Through the contribution of other documents, we used two sets of data: technical-scientific articles from journals from the electronic databases Web of Science Core Collection (WoS), Scopus (Elsevier), and Directory of Open Access Journals (DOAJ); and theses and dissertations from higher education institutions (HEI), through access to the Brazilian Digital Library of Theses and Dissertations (BDTD). The methodological approach included a systematic review of academic production and content analysis.

\subsection{Data extraction and selection}

For both sets of data, the beginning of the time frame was 01/01/1981, the year of enactment of the NEPA, until 01/30/2020. For the first set of data, the search terms in English, "Strategic Environmental Assessment" and "Brazil", supported the selection since part of the journals publish articles in English and the articles published in Portuguese have abstracts and keywords in that language. After applying the filters and eliminating duplications to meet the selection criteria, the sample resulted in 61 articles.

The authors obtained the other set of data by the search expression "Strategic Environmental Assessment" with filters for title, keywords, and abstract. The final sample resulted in 75 works: 33 theses and 42 dissertations.

\subsection{Data analysis}

\subsubsection{Quantitative data analysis}


We performed quantitative data analysis to reveal research trends and patterns regarding authorship, partnerships, themes, journals, and temporal distribution and origin. These themes are among those investigated by Caschili et al. (2014) and Li and Zhao (2015) in research on worldwide SEA. These data sets were subjected to descriptive statistical analysis simplified.

For the statistical treatment of the articles, we collected data regarding journals, authorship, keywords, and chronology. For theses and dissertations: IES, graduate programs (knowledge areas as standardized by Capes - Coordination for the Improvement of Higher Education Personnel), advisors, keywords, and chronology.

\subsubsection{Qualitative data analysis}

For the qualitative analysis, we adopted the classification proposed by Duarte, Dibo, and Sánchez (2017), adapted to the scope of this research, since SEA: i) is an IA instrument (SÁNCHEZ, 2017); ii) is complementary to the EIA (SILVA et al., 2014; TURCO; GALLARDO, 2018); iii) was not considered in the sample studied by these authors. The classification consists of:

i) Case analysis: describes PPP SEA processes, economy sector or spatial cutout, highlighting benefits and problems of the practice; cases are also classified between sectoral and territorial (or regional).

ii) Analysis of the SEA system: presents theoretical reflections on the SEA system (or lack thereof) in Brazil; studies can cover concepts, procedures, legislation, benefits and difficulties, and the relationship of SEA with other decision support instruments, as well as the legal/institutional system for application in different decision-making spheres.

iii) Discussions of methods and tools for SEA: analyzes or proposes technical resources for the application of SEA.

iv) Analysis of the quality of SEA reports: applies criteria to assess the quality of reports, exclusively; the focus is documental, differing from the first category.

Each document was entered into only one class. This classification was applied at two levels of content coverage:

i) in the theses and dissertations, we analyzed summaries and objectives to fit the classes and identify themes to represent an overview of academic research on SEA within the scope of Brazilian universities; other textual components were read-only when necessary to resolve doubts.

ii) the authors analyzed the articles in their entirety so that, in addition to framing the classes, their content could be explored to highlight the academic contribution in indexed journals.

To avoid biases, we classified each document separately by two of the three authors of the work in a rotating scheme. Only in cases of divergences, the third author also performed the classification. 


\section{Results and Discussions}

\subsection{Quantitative analysis of academic research on SEA in Brazil}

Figure 1 shows the publication frequency of the 61 articles analyzed in national and international journals, according to the four classes of analysis.

Figure 1 -Distribution of articles published on the SEA theme in national and international journals, considering the four classes of qualitative data analysis (upper part of the figure), and authorship and authors of articles published on the

SEA theme in national and international journals (bottom of the figure)

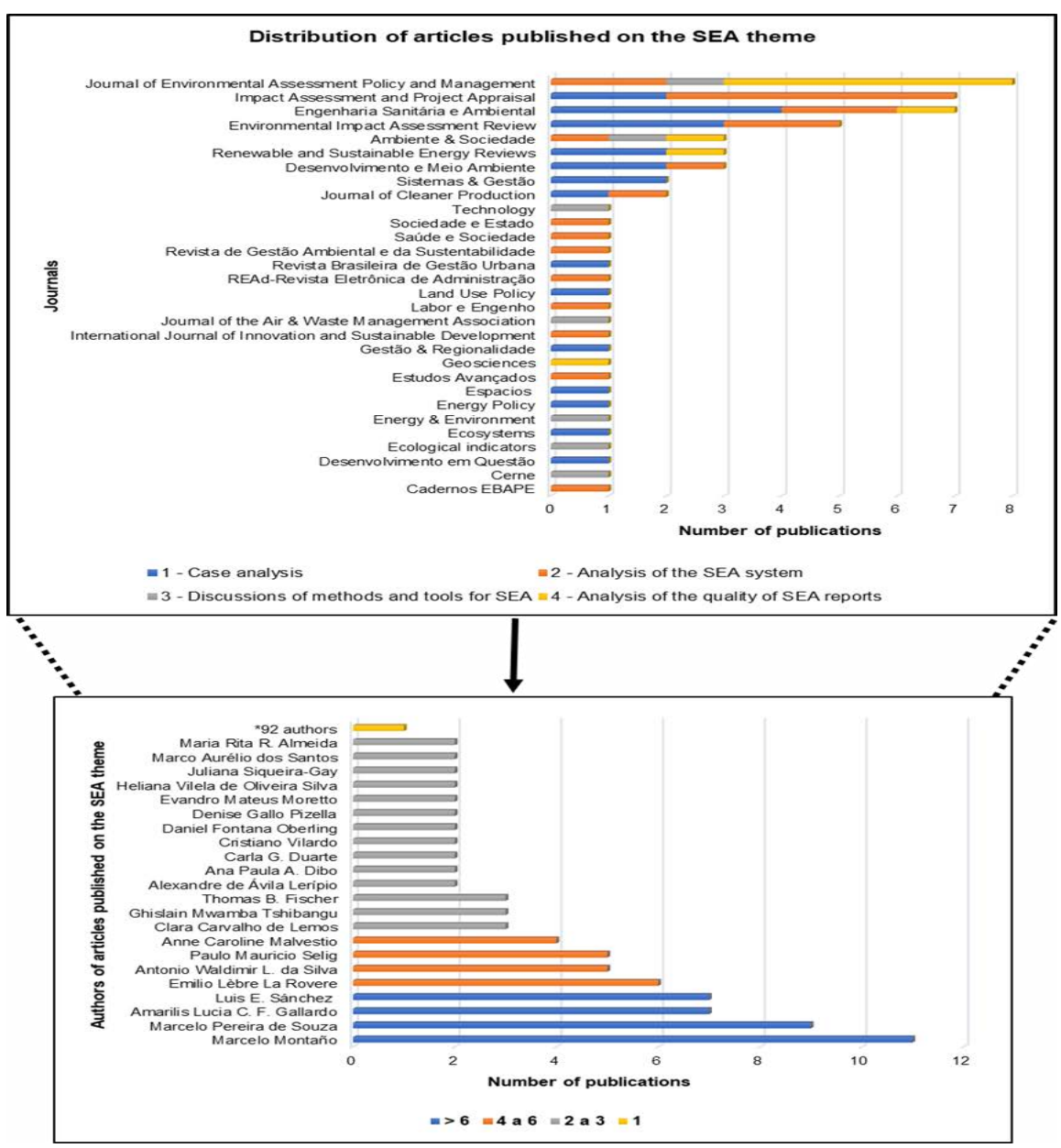

Source: the authors (2020).

As shown in Figure 1, the articles are published in 30 journals, 17 national and 13 international. From a total of 61 articles, 21 (35\% of the sample) are published in different journals (13 national and eight international) and mainly discuss case analysis and the SEA system. 40 articles (65\% of the sample) are concentrated in nine journals. 
Of these 40 articles, $40 \%$ are published in international journals and $25 \%$ in national ones, and mainly discuss case analysis and the SEA system. The two journals with the highest number of articles are international and comprise $25 \%$ of the sample. These are primarily articles on the analysis of the SEA system, followed by those that discuss the quality of reports.

According to Figure 1, for the 61 articles, there are 177 authorships (average of 2.9 authors per article) and 114 authors. Of these 114 authors, 22 account for 85 authors (48\%) of the 61 articles, while 92 (52\%) appear as authors of only one article. Of the 114 authors, only $11(10 \%)$ are not Brazilian, and two, one from Africa and the other from South America, completed postgraduate studies in the country, and nine are researchers in academic partnerships. Three Brazilian researchers are from institutions abroad or have a double relationship. Caschili et al. (2014) also verified this close worldwide research relationship network.

Considering the 22 authors with the highest number of publications, two are not Brazilian, one was a postgraduate in the country and the other is a professor at a university abroad. Of the authors who publish the most (more than two publications at least), the top four are responsible for 34 authorships (19\% of the articles), the next four by 20 authorships (11\% of the articles), and the other 14 authors by 31 authorship (18\% of the articles).

Figure 2 displays the distribution of theses and dissertations produced in Brazilian graduate programs (GPs), according to CAPES schools and areas. It presents the distribution of 75 theses and dissertations in the GPs of HEIs in the country and the professors responsible for guidance theses and dissertations produced on the theme SEA in the country. 
Figure 2 - Distribution of theses and dissertations produced in Brazilian GPs, according to CAPES schools and areas, considering the four classes of qualitative data analysis (figure on the left). Distribution of theses and dissertations produced in HEIs and the main guiding professors (central figure and on the right)

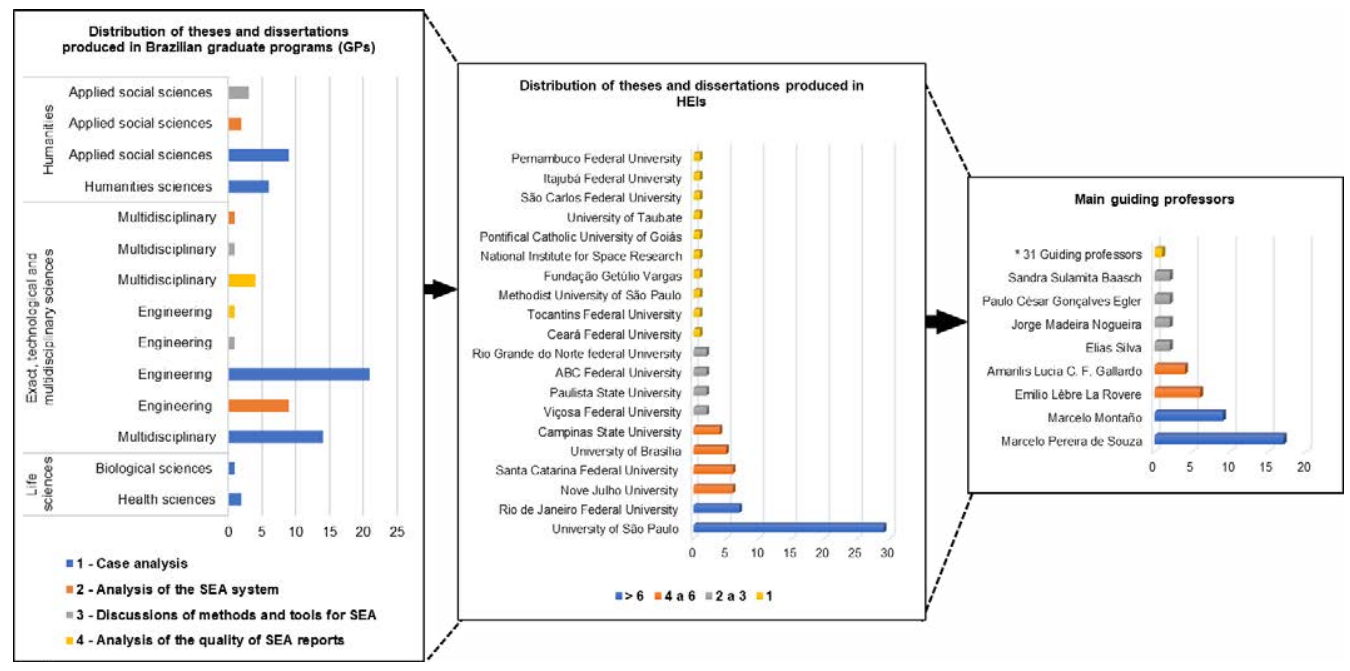

Source: the authors (2020).

Figure 2 exhibits that theses and dissertations on SEA produced in the three schools and six of the nine areas of CAPES, with greater representation in the exact, technological, and multidisciplinary sciences (50 theses and dissertations). In this college, the areas of CAPES in engineering (32) and multidisciplinary (20) cover research in the four classes analyzed, with a predominance of case studies. In the college of humanities, the area of applied social sciences (14) is distinctive as it does not present studies on SEA methods and tools, which are exclusive to the college of exact sciences. The humanities, from the college of humanities, and the biological sciences and health sciences, from the college of life sciences, have only SEA case study surveys.

There is no research in the areas of agrarian sciences; linguistics, letters, and arts; and exact and Earth science. These results differ from those found by Caschili et al. (2014) in the SEA worldwide survey. Of the 12 scientific sectors considered by these authors, the areas of multidisciplinary knowledge and engineering are among those that concentrate the least number of scientific works, conversely, the ones that most stand out are environmental and urban planning.

According to Figure 2, in Brazil, 20 universities from all regions (13 - Southeast, 3 - Northeast, 2 - Midwest, 1 - Northeast, and 1 - South) have theses and dissertations defended on the subject. However, there is a high incidence for HEIs in the Southeast - 73\% of the total; the University of São Paulo accounts for 39\% of these. The six universities $(30 \%)$ with the highest number of theses and dissertations defended account 
for $76 \%$ of this production.

We observed in Figure 2 that 39 teachers guided the 75 theses and dissertations on SEA in the country. Of the only eight professors who supervised more than two surveys, two are responsible for almost $35 \%$ of the orientations in the country and the four advisors most frequently answer for $48 \%$ of these orientations. The two main advisors are also those who publish the most about SEA in the country, likely denoting the origin of the academic research articles. The other two teachers with the highest frequency of orientation are also among those who publish the most articles (Figure 1), reinforcing this assertion. Figure 3 shows the frequency of keywords in academic production on SEA in the country.

Figure 3 - Distribution of frequencies of keywords in theses and dissertations and in articles on SEA in Brazil

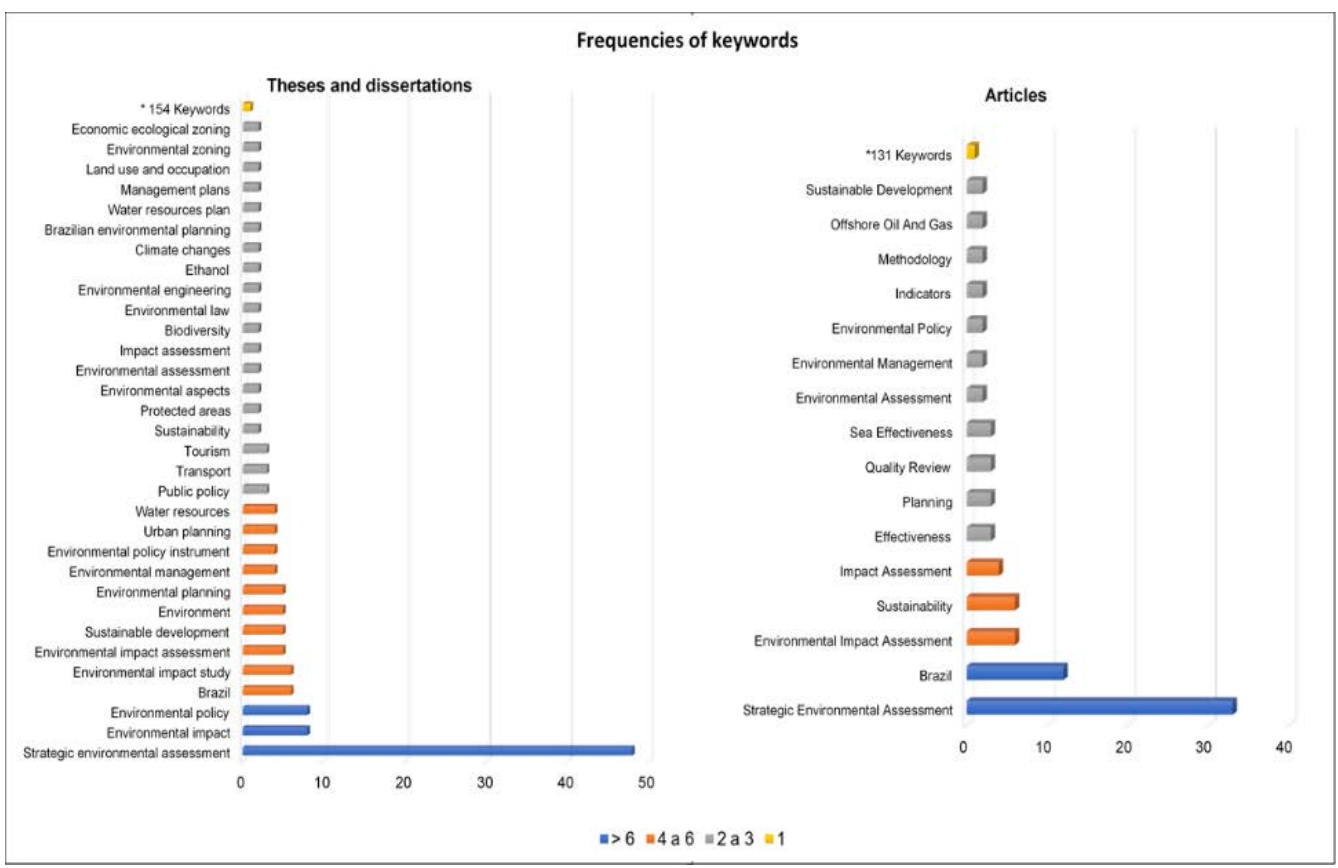

Source: the authors (2020).

Figure 3 shows 147 keywords (in English) in the articles. Of the 16 most mentioned, the two with the highest frequency mention the instrument itself and the country; next, the others cite EIA, IA, and sustainability that are directly associated with SEA; and the others adhere to the analysis categories. Regarding theses and dissertations, we observed 186 keywords. Among the 32 most cited, the word SEA is most prevalent, followed by environmental policy and environmental impact; the ten other most frequent keywords show a connection with other IA instruments, environmental management and planning, water resources, and urban planning. 
These two sets of collated keywords allow us to consider the need to emphasize the instrument itself, 54\% of the articles and $64 \%$ of the theses and dissertations mention SEA, as verified by Caschili et al. (2014). In the articles, except for the oil and gas sector, the most frequent keywords do not highlight sectors or territorial cuts and are more associated with other instruments and terms related to effectiveness and methods. In theses and dissertations, there is a wide range of keywords that allow associating SEA to various instruments, plans, sectors, territorial areas, and themes, with no mention of terms referring to methodologies and analysis of SEA systems.

The scope of the areas of origin of theses and dissertations can perhaps justify this diversity of keywords that reveal the connection with many areas of public policy, planning, and decision-making. In turn, the keywords of the articles show a greater alignment with intrinsic aspects of the application of the instrument. This diversity of keywords corroborates the survey by Caschili et al. (2014) on the multidisciplinarity of SEA that spans a variety of sectors and lines of research. Figure 4 presents the chronology of Brazilian academic research on SEA.

Figure 4 - Chronological distribution of the publication of articles and the defense of theses and dissertations. The upper part of the figure details this distribution over time, considering the four classes of qualitative data analysis.

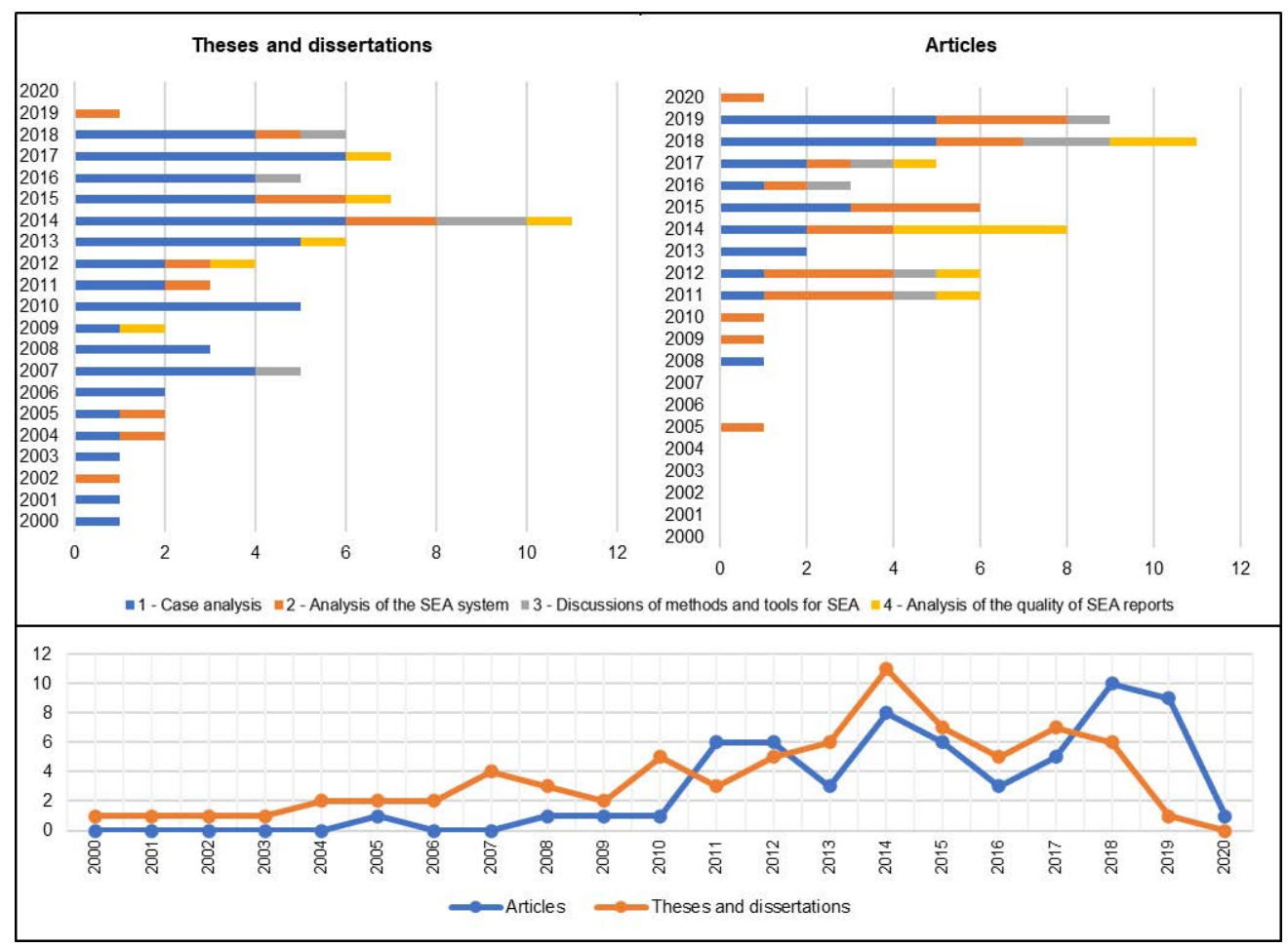

Source: the authors (2020).

Figure 4 shows that theses and dissertations on SEA in Brazil started to be defended 
from the year 2000, with the first article published only in 2005. The articles started to be systematically published from 2008, alternating periods of rise and fall in production, reaching the highest level in recent years (2018 and 2019).

Only 2020 has zero records of theses and dissertations as the survey was closed in the first month of the year. In just two moments, the number of articles was higher than the number of theses and dissertations (2011 to 2012; 2018 to 2020). The maximum number of productions for theses and dissertations was reached in 2014 (11) and, for articles in 2018 (10).

Excluding the year 2020, there is a trend of growth in the number of publications since 2016, and a drop in theses and dissertations from 2014 onwards. SEA is still relatively recent and centralized in some researchers from some universities, frequency oscillations can occur due to different factors, many of which are not discussed here. It is believed that it would be immature with the data obtained to support justifications for these trends.

Regarding the analysis classes, Figure 4 shows that the scope of research in the four classes presents a more systematic pattern for articles from 2011 onwards and for theses and dissertations from 2014 onwards. This reveals that the scope of the work remained more diverse only in the second half of the timeline.

The cases of quality of SEA reports appear later in the set of Brazilian academic production, in 2009 in articles, and 2011 in theses and dissertations, that is, only when the practice was in progress, and there was material for this analysis. The class of tools and methods appears for the first time in theses and dissertations, in 2007, and articles, in 2011, denoting a spaced distribution pattern in the years after these initial milestones, revealing to be a little explored and less systematic theme.

The case analysis class is distributed throughout the period of theses and dissertations, except for the years 2002 and 2019, and in the articles, it appears, recurrently from 2011, denoting the preference for research of this nature throughout the period of academic production.

\subsection{Qualitative analysis of academic research on SEA in Brazil}

The 61 articles are distributed in: i) 23 - case analysis; ii) 22 -analyses of the SEA system; iii) seven - discussions of methods and tools for SEA; iv) nine - analyses of the quality of SEA reports, as indicated in Figure 1.

The 75 theses and dissertations are divided into i) 53 - case analysis; ii) 11-analyses of the SEA system; iii) five - discussions of methods and tools for SEA; iv) six - quality analysis of SEA reports, as shown in Figure 5. 
Figure 5 - Distribution and classification of theses and dissertations in the four classes of analysis qualitative data

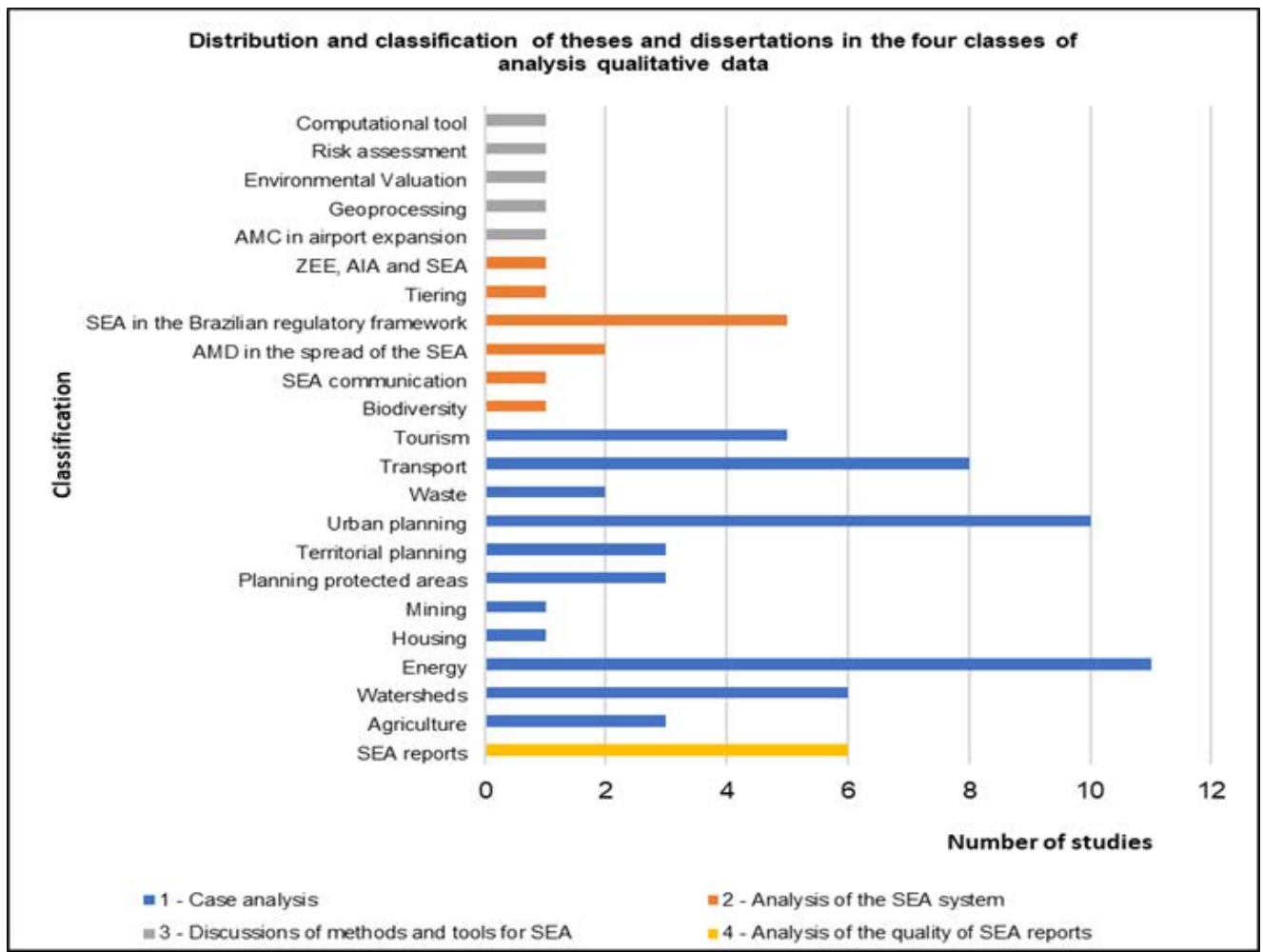

Note: On the y axis, in addition to the classification in the four classes of analysis, the themes of each thesis and dissertation identified by reading the abstract are listed.

Source: Prepared by the authors (2020).

The distribution of articles and theses and dissertations is similar to that found by Duarte, Dibo, and Sánchez (2017) for two of the four classes, in which case analyses and the SEA system prevail, with greater representation of cases. However, in the case of the AIA discussion, Duarte, Dibo, and Sánchez (2017) identified that the method and tool class has more studies than the report quality class, the opposite of what was observed in this study with SEA.

\subsubsection{Case Analysis}

The case analysis category is the most frequent in the 75 theses and dissertations (Figure 5). There are 53 theses and dissertations ( 32 from sectoral analysis and 21 from 
territorial analysis), addressing 11 themes (from highest to lowest frequency: energy, urban planning, transport, watershed, tourism, agriculture, territorial planning, area planning protected areas, waste, mining, and housing).

Of the 61 articles, 23 were framed in this category, 15 of sectoral analysis (energy, transport, waste, fishing, and tourism), and eight of territorial analysis (land use, urban planning, hydrographic basins, agriculture, and the Blue Amazon), as displayed in Figure 1. Duarte, Dibo, and Sánchez (2017) also discovered a higher incidence of analysis of cases in the energy sector. Regarding the cases analyzed in theses and dissertations compared to articles, although at a much higher frequency, practically the same themes are verified, except for mining and fishing. This denotes that practically the scope of research performed at universities was published in journals.

The articles classified as case analysis discuss the application of SEA to the main milestones of national planning, from policies to plans such as the National Energy Plan (NEP 2030) (SANTOS E SOUZA, 2011) and NEP 2050 (ANDRADE; SANTOS, 2015; MYSZCZUK ; SOUZA, 2018), Ten-Year Energy Expansion Plan (PDE 2024), (HOFFMANN; CARDOSO Jr., 2018), Transport PPP (ZIONI; FREITAS, 2015; MALVESTIO; FISCHER; MONTAÑO, 2018), National Waste Policy Solids (VIEIRA et al., 2019), river basin plans (PIZELLA; SOUZA, 2015; ÁVILA, 2018; FABBRO NETO; SOUZA, 2017), land use plans in urban areas (FABBRO NETO; SOUZA, 2017; SIQUEIRA, 2017; -GAY; SÁNCHEZ, 2019), rural (OBERLING; LA ROVERE; OLIVEIRA SILVA, 2013; ESTEVES; SOUZA, 2014), and coastal (SANTOS; TEIXEIRA, 2012).

In terms of sectoral cases, it is observed that the contributions are directed towards the integration of SEA to other NEPA instruments, called tiering or chaining (TURCO; GALLARDO, 2018): in the transport sector between AIA and SEA (SÁNCHEZ; SILVA -SÁNCHEZ, 2008); between SEA and the Ecological-Economic Zoning (EEZ) (ZIONI; FREITAS, 2015); in the hydroelectric sector, regarding the scope of the EIA in the planning and role of the SEA (ANDRADE; SANTOS, 2015), the integration of the SEA regarding the cumulative impact assessment (CIA) of small hydropower plants (ATHAYDE et al., 2019), multiple pre-salt projects (VILARDO; LA ROVERE, 2018), and hydroelectric plants (WESTIN; SANTOS; MARTINS, 2014).

In terms of territorial or regional cases, it is observed that the contributions are mainly directed to SEA, providing the integration of planning at different scales, territorial cuts (regional to local) and sectoral (OBERLING; LA ROVERE; OLIVEIRA SILVA, 2013; PIZELLA; SOUZA, 2013; ESTEVES; SOUZA, 2014; FABBRO NETO; SOUZA, 2017). The SEA supports strategic planning such as the environmental release of transgenic cultivars (PIZELLA; SOUZA, 2015), the protection of the Blue Amazon (SANTOS; TEIXEIRA, 2012), and social housing plans (SIQUEIRA-GAY; SÁNCHEZ, 2019).

These cases highlight that SEA has the potential to overcome environmental licensing bottlenecks (ANDRADE; SANTOS, 2015; HOFFMANN; CARDOSO Jr., 2018; MYSZCZUK; SOUZA, 2018; VILARDO; LA ROVERE, 2018) in terms of concatenating the temporal sequence, scope of other IA instruments in planning (WESTIN; 
SANTOS; MARTINS, 2014; VILARDO; LA ROVERE, 2018; ATHAYDE et al., 2019); subsidize the wind energy expansion strategy in the country (DA SILVA et al., 2019); strengthen the implementation of plans resulting from public policies such as in tourism (LEMOS, FISCHER; SOUZA, 2012) and in the waste sector (VIEIRA et al., 2019); integrate sectoral and territorial plans (OBERLING; LA ROVERE; OLIVEIRA SILVA, 2013; FABBRO NETO; SOUZA, 2017; SANTOS; TEIXEIRA, 2017); leverage sectors of the economy such as fishing (MELO; FREIRE, 2016); and guide the use of land and sea land in strategic activities (PIZELLA; SOUZA, 2015; SANTOS; TEIXEIRA, 2012; SIQUEIRA-GAY; SÁNCHEZ, 2019).

Regarding difficulties and barriers, they feature an economic approach to planning focused on short-term demands (MALVESTIO, FISCHER; MONTAÑO, 2018); institutional configuration and lack of institutional cooperation and participatory processes (SANTOS E SOUZA, 2011; MALVESTIO, FISCHER; MONTAÑO, 2018); the subjectivity of political planning processes in the country (HOFFMANN; CARDOSO Jr, 2018); conflicts between economic and environmental protection policies (MYSZCZUK; SOUZA, 2018; ESTEVES; SOUZA, 2014); lack of environmental and social data in decision making (OBERLING; LA ROVERE; OLIVEIRA SILVA, 2013); and the absence of a formal system hampering the definition of strategic issues and generating conflicts at the project level (SÁNCHEZ; SILVA-SÁNCHEZ, 2008; ANDRADE; SANTOS, 2015; MALVESTIO, FISCHER; MONTAÑO, 2018).

Several articles highlight the need for regulation of SEA in the country (SÁN. CHEZ; SILVA-SÁNCHEZ, 2008; SANTOS; SOUZA, 2011; PIZELLA; SOUZA, 2013; MALVESTIO, FISCHER; MONTAÑO, 2018; MYSZCZUK; SOUZA, 2018; HOFFMANN; CARDOSO Jr., 2018; ATHAYDE et al., 2019).

\subsubsection{Analysis of the SEA system}

The SEA system analysis category is the second most frequent in the 75 theses and dissertations (Figure 5). Among them, 11 discuss tiering, SEA, and other instruments such as zoning and EIA, SEA in the Brazilian regulatory framework, the role of multilateral development agencies in dissemination of SEA, communication, and the biodiversity theme.

Of the 61 articles, the 22 in this category (Figure 1) discuss the need for SEA in the environmental regulatory framework and concepts and guidelines for strengthening the SEA system in the country.

Practically all theses and dissertation themes are present in the articles, except for the inclusion of biodiversity in SEA systems. However, the articles cover other topics such as effectiveness, teaching, formalization, and flexibility of SEA in the country, which are not present in theses and dissertations. The fact that the articles also double the number of theses and dissertations in this class reinforces that many may or may not be an offshoot of these or resulting from other research projects of the authors involved.

In Figure 1, the oldest articles in this category, from 2005 and 2012, discuss the potential contributions of the introduction of SEA in the Brazilian legal framework, 
strengthening environmental policies, and overcoming gaps in the EIA (GALLARDO; BOND, 2011; SANGUINETTO, 2011); the expansion of social participation created by the AIA (COSTA et al., 2009); and the role of the Federal Court of Accounts (FCA) and multilateral funding agencies for the dissemination of SEA in the national territory (LIMA, 2005; PELLIN et al., 2011). Sehnem et al. (2012) conducted a bibliometric survey on environmental themes in Brazilian administration journals, from 2000 to 2009, and found that only two of the 113 papers dealt with SEA. Alternately, Sánchez and Morrison-Saunders (2010), in a survey of professionals from 18 countries, between 2008 and 2009, observed SEA as the second most frequent type of IA instrument, after EIA.

The role of multilateral development agencies is the subject of two works. Pellin et al. (2011) and Tshibangu and Montaño (2016) expressed concerns about the SEA development model, under this sponsorship, in developing countries as a requirement for investment approval. For these authors, the strategic discussion loses space in the face of primarily economic demand, and in some cases, SEA starts after relevant decisions have been taken.

The most recent articles, from 2014 and 2020, present assessments of the local experience, recommendations for advancing the practice and consolidation of a formal SEA system (MONTAÑO et al., 2014; ALMEIDA et al., 2015; SÁNCHEZ, 2017; MALVESTIO ; MONTAÑO, 2019; MONTAÑO; FISCHER, 2019; VILARDO et al., 2020); contributions to the literature, not only local but international in terms of concepts, characteristics of SEA, practice in developing countries and teaching of SEA in the higher education curriculum (SILVA et al., 2014; RAMOS et al., 2015; SILVA ; SELIG, 2015; SANTI et al., 2018; TSHIBANGU, 2018).

In terms of attempts to formalize the SEA, the contribution of the Ministry of the Environment, in 2010, without continuity by the government, was discussed by Almeida et al. (2015) who highlighted as positive aspects the forecast of society's participation, and negative aspects which are the lack of definition of responsibilities and procedures. Vilardo et al. (2020) discuss the repercussions of the suspension of the implementation of the Environmental Assessment of Sedimentary Areas (EASA). According to these authors, it would be a type of SEA, designed in 2012 for the oil and gas sector, whose positive results have not yet been seen due to recent changes in the institutional and political context of Brazil, which will certainly burden the EIA of projects.

According to Montaño et al. (2014), the Brazilian practice of SEA has slowly evolved since the first experience in the 1990s, but the absence of institutional guidelines and procedural structure hinders the development of a Brazilian SEA system. Tshibangu and Montaño (2019) recognize the potential of the systematic use of SEA to positively influence strategic actions but credit the lack of adequate legislation and the influence of the practice of EIA and the culture of licensing engineering projects as obstacles to its consolidation. In this sense, Sánchez 2017) states that efforts to formalize should be directed towards public policies, showing their advantages, to the detriment of the perception of reduced discretion of decision-makers.

To structure the Brazilian SEA system that suffers from excessive flexibility, ac- 
cording to Malvestio and Montaño (2019), there must be a formal definition of SEA procedures and objectives in planning; incentives for using SEA at the strategic stages of decision making and at the appropriate time.

Montaño and Fischer (2019) add that the guidelines can contribute to the development of SEA provided that they allow them to go beyond the minimum legal requirements, be adapted to specific cases, and establish a minimum standard to promote the advancement of SEA quality in decision-making.

Different from what Duarte, Dibo, and Sánchez (2017) observed for this class, as the EIA is a mandatory instrument in the country, weaknesses were indicated amid some positive results and advances. The survey for the SEA, which is voluntary, highlighted the potential and guidelines for expanding its regular use and avoiding the pitfalls in this consolidation.

\subsubsection{Discussions of methods and tools for SEA}

Of the 75 theses and dissertations (Figure 5), five refer to methods and tools (computational tool, risk assessment, environmental valuation, geoprocessing, and multicriteria analysis).

Of the 61 articles, seven (Figure 1) discuss methods and techniques for developing SEA processes and reports. The comparison between these documents denotes overlapping themes, apart from articles that deal with methodological propositions for the use of SEA in the country.

Contributions to improvements in SEA processes are observed in Gallardo, Duarte, and Dibo (2016), who proposed an SEA roadmap to support the planning of sugarcane expansion, based on good international practices and using a basket of indicators of sustainability.

For Silva et al. (2019), the use of indicators allows for the development of a governance model for SEA processes. The other works focus on improving procedures for steps in the preparation of SEA: fuzzy logic, associated with hierarchical analysis and GIS, is recommended by Oliveira et al. (2012) for the diagnosis step and by Secron et al. (2017), to study alternatives and to Cavalcanti and La Rovere (2011) in the evaluation of strategic options. Carvalho (2011) discusses scenarios with geoprocessing tools and Ferreira et al. (2019), SEA subsidies in territorial planning guided by the offer of ecosystem services.

Also different from what was observed by Duarte, Dibo, and Sánchez (2017) for this class, the weaknesses of the EIA phases are widely discussed, as it is a mandatory instrument, and in the case of SEA, tools, and technical instruments add value to its use although the instrument is still voluntary in the country.

\subsubsection{Quality analysis of SEA reports}

Of the 61 articles, nine (Figure 1), and of the 75 theses and dissertations, six (Figure 5), discuss the quality of Brazilian SEA reports based on evaluation criteria recommended 
in the literature.

Margato and Sánchez (2014) evaluated 24 reports, from 1994 to 2011, finding the following deficiencies: lack of analysis of alternatives, limited social participation, and weak link with decision-making. Silva et al. (2014) assessed the quality of three reports requested by different agents (ministry of environment, state environment secretariat, and a non-governmental organization) and stressed the lack of articulation of SEA to decision-making but noted progress in public participation and dissemination knowledge provided by SEA.

Malvestio and Montaño (2013) analyzed the procedural effectiveness of nine energy reports, highlighting the lack of formal requirements and the influence of EIA rationalism, corroborating the diagnosis of the absence of SEA procedures. The works of Rizzo, Gallardo, and Moretto (2017), Crespo and Raimundo (2018), and Mota, La Rovere, and Fonseca (2014) evaluated reports using the same criteria, revealing variable results regarding their quality and expectations of good international practices.

Motivated by the SPCC that recommends the use of SEA, Nadruz et al. (2018) evaluated 35 reports regarding the insertion of climate change, verifying that mitigation and adaptation measures are rare, revealing a gap in achieving the goals of the climate agreements.

Two studies assessed the quality of SEA reports using sustainability indicators. Silva, Selig, and Morales (2012) evaluated 28 reports from 21 countries and Silva, Selig, and Van Bellen (2014), reviewed 32 Brazilian reports, revealing that almost all Brazilians use indicators, while international ones use much less, referring to local lessons for the worldwide practice.

The main lessons refer to in non-regulated systems, SEA needs to be linked to a defined decision context so that its value is discernible (MARGATO; SÁNCHEZ, 2014); dissemination of knowledge about SEA and adding sustainability, even when applied late in decision-making processes (SILVA et al., 2014); need to regulate the instrument and a formal system (CRESPO; RAIMUNDO, 2018; NADRUZ et al., 2018); and use as a corporate planning tool (MOTA; LA ROVERE; FONSECA, 2014).

Duarte, Dibo, and Sánchez (2017) verified analysis of single cases of EIA; conversely, this research reveals that SEA quality analysis is marked by multiple cases, mainly to demonstrate the alignment of local practice with international good practices, rather than highlighting specific aspects.

\section{Final Considerations}

Brazilian academic research on SEA has been represented, since 2000, by 42 dissertations and 33 theses, supervised by 39 professors from 20 universities from all Brazilian regions, with a predominant concentration in the Southeast region; and, since 2005, for 61 articles, from 114 authors, published in 17 national and 13 international journals.

With a strong role played by a group of researchers, it is a research area at an early 
stage of development such as AIA in Brazil (DUARTE; DIBO; SÁNCHEZ, 2017), with a small research network, such as the SEA in the world (CASCHILI et al., 2014), but with multidisciplinary representation in the areas of national knowledge.

Although most (54\%) of the articles are published in international journals, a small portion of authorship (10\%) is not national. It can be concluded that research by Brazilian universities on SEA has been published in journals of interest to the international audience, but with international partnerships, at least formal or with limited published products.

Academic research on SEA in Brazil reveals a wide field of application in local PPPs, in different sectors and territories, although often in the theoretical and prospective field, given that the instrument is not mandatory in the country. SEA appears not only as an instrument to overcome project EIA bottlenecks (SÁNCHEZ; SILVA-SÁNCHEZ, 2008; ANDRADE; SANTOS, 2015), although this facet is explored to enhance the instrument, it demonstrates versatility to integrate with others instruments of the NEPA, such as zoning (ZIONI; FREITAS, 2015); and AIC (ATHAYDE et al., 2019) and to strengthen the tiering (TURCO; GALLARDO, 2018).

In terms of building an SEA system, the first discussions focused on contributions to the environmental regulatory framework (GALLARDO; BOND, 2011; SANGUINETTO, 2011). The most recent recommendation is consolidating a formal SEA system beyond the local SEA application (MONTAÑO et al., 2014; ALMEIDA et al., 2015; SÁNCHEZ, 2017; MALVESTIO; MONTAÑO, 2019; MONTAÑO; FISCHER, 2019; VILARDO et al., 2020). However, the lack of procedures, legislation (TSHIBANGU; MONTAÑO, 2019), a culture of environmental licensing (SÁNCHEZ, 2017; (TSHIBANGU; MONTAÑO, 2019), and a very flexible system are obstacles in the country (MALVESTIO, FISCHER; MONTAÑO, 2018).

If the Brazilian practice shows a slow evolution, the attempts to formalize SEA at the federal level are disappointing due to their non-continuity (ALMEIDA et al., 2015; VILARDO et al. 2020), and due to the low technical and procedural scope (MONTAÑ et al., al., 2014). Another limiting aspect is when to trigger the SEA process and who should promote it. FCA has recommended it (LIMA, 2005), but it is the multilateral development agencies that have been the main sponsors for local SEA initiatives (PELLIN et al., 2011), but often disconnected from the strategic dimension and initiated after-thefact (TSHIBANGU; MONTAÑO, 2016). Strategic actions and public policies (LEMOS, FISCHER; SOUZA, 2012; SÁNCHEZ, 2017; CRESPO; RAIMUNDO, 2018; VIEIRA et al., 2019), in the view of local works, seem to be the most appropriate moments in the decision-making chain to start the SEA processes.

Contributions to procedural and process improvements are reduced, reinforcing the incipient character of research and unregulated practice. The analysis of the Brazilian SEA reports reveals positive evidence of technical quality, procedural effectiveness, knowledge dissemination, public participation, and inclusion of sustainability. Negative signs are evident, such as lack of transparency and regulation, timing, tiering, procedures and integration of major environmental issues, low influence on decision-making, and 
lack of monitoring.

Academic research shows that to structure a future Brazilian SEA system, it is necessary to provide institutional guidelines, procedural structure, legislation, link with the planning process, formal definition of procedures, and timely application of strategic decision-making.

The difficulties and barriers consist of planning with an economic bias and focused on short-term demands; lack of institutional cooperation and participatory processes; the subjectivity of planning processes in the country; conflicting development and protection agendas; but, mainly, that the vacancy of a formal SEA system, in addition to emptying the environmental issue at the strategic level, still burdens this assessment at the project level.

The analysis of the temporal evolution of Brazilian research demonstrates a small production (four productions on average/year) but perennial, denoting that the voluntary nature of the instrument did not inhibit its appreciation in the academic environment, in the process of internalization in Brazilian research.

The analysis of cases has a regular distribution in the period, showing the interest in exploring the application of the instrument, even in a non-formalized system. The research shows a maturity of scope from 2011 with works in the four analysis classes. Less frequent quality reporting studies also appear from that date onwards, when there was material to feed this analysis; and the methods and tools are later and sparse revealing an even more limited research interest.

We conclude that it is necessary to move beyond the current stage of research, mainly focused on the potential benefits of integrating SEA into the Brazilian regulatory framework, but not audacious enough to propose guidelines and procedures for the Brazilian context.

We recommend that research perspectives, in line with recent work, should be directed towards effectively fostering and building a Brazilian legal framework for SEA. This recommendation is in line with that is endorsed by Sánchez (2017) on the need to find formulas to institutionalize and even make SEA mandatory in the country, showing its advantages to decision-makers and contributing to public and private decisions that are convergent with the expectation of a sustainable future.

\section{Acknowledgment}

The first author gratefully acknowledges FAPESP, grant Fapesp 2019/18.988-9, Foundation for Research Support of the State of São Paulo (Fapesp), and CNPq, grant CNPq 303542/2020-9, Brazilian National Council for Scientific and Technological Development, and the third author also thanks CNPq, grant CNPq 306244/2020-9. 


\section{References}

ALMEIDA, M. R. R.; et al. Analysis of the proposed federal implementation of Strategic Environmental Assessment in Brazil. Revista de Gestão Ambiental e da Sustentabilidade, v. 4, n. 2, p. 18-33, 2015.

ANDRADE, A. L.; SANTOS, M. A. Hydroelectric plants environmental viability: Strategic Environmental Assessment application in Brazil. Renewable and Sustainable Energy Reviews, v. 52, p. 1413-1423, 2015.

ATHAYDE, S.; et al. Improving policies and instruments to address cumulative impacts of small hydropower in the Amazon. Energy Policy, v. 132, p. 265-271, 2019.

CAPE, L.; et al. Exploring pluralism-Different stakeholder views of the expected and realized value of strategic environmental assessment (SEA). Environmental Impact Assessment Review, v. 69, p. 32-41, 2018.

CARDOSO JR, R. A. F; HOFFMANN, A. S. Environmental Licensing Challenges of Xingu Rio Transmission System Route Definitions. Ciência e Natura, v. 40, p.e75, 2018.

CARVALHO, C. M. Strategic Environmental Assessment for sustainable expansion of palm oil biofuels in Brazilian north region. Energy $\&$ environment, v. 22, n. 5, p. 565-572, 2011.

CASCHILI, S.; et al. The Strategic Environment Assessment bibliographic network: A quantitative literature review analysis. Environmental Impact Assessment Review, v. 47, p. 14-28, 2014.

CAVALCANTI, P. M. P. S.; LA ROVERE, E. L. Strategic environmental assessment of mining activities: a methodology for quantification of cumulative impacts on the air quality. Journal of the Air \& Waste Management Association, v. 61, n. 4, p. 377-389, 2011.

COSTA, H. A.; BURSZTYN, M. A.; NASCIMENTO, E. P. do. Participação social em processos de avaliação ambiental estratégica. Sociedade e Estado, Brasília, v. 24, n. 1, p. 89-113, 2009.

CRESPO, B. R. M.; RAIMUNDO, M. R. Discussão de alternativas nos processos de Avaliação Ambiental Estratégica em Minas Gerais. Geociências, v. 37, n. 4, p. 909-920, 2018.

DÁVILA, J. G.; AZCÁRATE, J.; KORNOV, L. Strategic Environmental Assessment for development programs and sustainability transition in the Colombian post-conflict context. Environmental Impact Assessment Review, v. 74, p. 35-42, 2019.

DUARTE, C. G.; DIBO, A. P. A.; SÁNCHEZ, L. E. What does the academic research say about impact assessment and environmental licensing in Brazil?. Ambiente $\&$ Sociedade, v. 20, n. 1, p. 261-292, 2017.

ESTEVES, A. O.; SOUZA, M. P. Avaliação Ambiental Estratégica e as áreas de proteção ambiental. Engenharia Sanitária e Ambiental, v, 19, p. 77-86, 2014.

FABBRO NETO, F.; SOUZA, M. P. D. O planejamento integrado de bacia hidrográfica e uso do 
solo na Escócia. Engenharia Sanitária e Ambiental, v. 22, n. 6, p. 1215-1223, 2017.

FERREIRA, S. F; et al. Environmental impact assessment of end-uses of biomethane. Journal of Cleaner Production, v. 230, p. 613-621, 2019.

GALLARDO, A. L. C. F; BOND, A. Capturing the implications of land use change in Brazil through Environmental Assessment: Time for a strategic approach? Environmental Impact Assessment Review, v. 31, n. 3, p. 261-270, 2011.

GALlARDO, A. L. C. F; DUARTE, C. G.; DIBO, A. P. A. Strategic Environmental Assessment for planning sugarcane expansion: a framework proposal. Ambiente $\mathbb{\&}$ Sociedade, v. 19, n. 2, p. 67-92, 2016.

GENELETTI, D. Assessing the impact of alternative land-use zoning policies on future ecosystem services. Environmental Impact Assessment Review, v. 40, p. 25-35, 2013.

LARSEN, S. V.; KORNOV, L.; DRISCOLL, P. Avoiding climate change uncertainties in Strategic Environmental Assessment. Environmental Impact Assessment Review, v. 43, p. 144-150, 2013.

LEMOS, C. C.; FISCHER, T. B.; SOUZA, M. P. Strategic environmental assessment in tourism planning-Extent of application and quality of documentation. Environmental Impact Assessment Review, v. 35, p. 1-10, 2012.

LI, Wei; ZHAO, Yang. Bibliometric analysis of global environmental assessment research in a 20year period. Environmental Impact Assessment Review, v. 50, p. 158-166, 2015.

LIMA, L. H. M. D. O Tribunal de Contas da União (TCU) e a gestão ambiental brasileira: experiência recente. Cadernos EBAPE, v. 3, n. 3, p. 01-13, 2005.

MALVESTIO, A. C.; FISCHER, T. B.; MONTAÑO, M. The consideration of environmental and social issues in transport policy, plan and programme making in Brazil: A systems analysis. Journal of Cleaner Production, v. 179, p. 674-689, 2018.

MALVESTIO, A. C.; MONTAÑO, M. Effectiveness of Strategic Environmental Assessment applied to renewable energy in Brazil. Journal of Environmental Assessment Policy and Management, v.15, n. 2, 2013.

MALVESTIO, A. C.; MONTAÑN, M. From medicine to poison: how flexible Strategic Environmental Assessment may be? Lessons from a non-regulated SEA system. Impact Assessment and Project Appraisal, v.37, n. 5, p. 437-451, 2019.

MARGATO, V.; SÁNCHEZ, L. E. Quality and outcomes: a critical review of Strategic Environmental Assessment in Brazil. Journal of Environmental Assessment Policy and Management, v. 16, n. 02, 2014.

MELO, H.S.; FREIRE, G. S. S. Avaliação Ambiental Estratégica como alavanca para o desenvolvimento da pesca. Innovation system, productive organization, culture and local knowledge. 
Espacios, v. 37, n. 35, p.19, 2016.

MONTAÑO, M.; FISCHER, T. B. Towards a more effective approach to the development and maintenance of sea guidance. Impact Assessment and Project Appraisal, v. 37, n. 2 p. 1-10, 2018.

MONTAÑO, M.; SOUZA, M.P. Impact Assessment research in Brazil: Achievements, gaps and future directions. Journal of Environmental Assessment Policy and Management, v.17, n.1, p. $1550009,2015$.

MONTAÑO, M.; et al. Current state of the SEA system in Brazil: a comparative study. Journal of Environmental Assessment Policy and Management, v. 16, n. 02, p. 1450022, 2014.

MONTEIRO, M. B.; PARTIDÁRIO, M. R. Governance in Strategic Environmental Assessment: Lessons from the Portuguese practice. Environmental Impact Assessment Review, v. 65, p. 125-138, 2017.

MOTA, A. C.; LA ROVERE, E. L.; FONSECA, A. Industry-driven and civil societydriven strategic environmental assessments in the iron mining and smelting complex of Corumbá, Brazil. Journal of Environmental Assessment Policy and Management, v. 16, n. 02, p. 1450010, 2014.

MYSZCZUK, A. P.; SOUZA, A. O Setor Elétrico Brasileiro e Alguns Conflitos Entre as Políticas Públicas de Proteção ao Meio Ambiente e de Desenvolvimento Econômico. Desenvolvimento em Questão, v. 16, n. 43, p. 200-233, 2018.

NADRUZ, V. N.; et al. Identifying the missing link between climate change policies and sectoral/ regional planning supported by Strategic Environmental Assessment in emergent economies: lessons from Brazil. Renewable and Sustainable Energy Reviews, v. 88, p. 46-53, 2018.

OBERLING, D. F.; LA ROVERE, E. L.; DE OLIVEIRA SILVA, H. V. SEA making inroads in land-use planning in Brazil: The case of the Extreme South of Bahia with forestry and biofuels. Land Use Policy, v. 35, p. 341-358, 2013.

OLIVEIRA, D. B. B.; et al. Multi-criteria analysis in the strategic environmental assessment of the sugar and alcohol sector. Acta Scientiarum. Technology, v.34, n. 3, p. 303-311, 2012.

PELLIN, A.; et al. Strategic environmental assessment in Brazil: debates regarding the role of multilateral development agencies. Engenharia Sanitária e Ambiental, v. 16, n. 1, p. 27-36, 2011.

PHYLIP-JONES, J.; FISCHER, T. B. Strategic Environmental Assessment (SEA) for wind energy planning: lessons from the United Kingdom and Germany. Environmental Impact Assessment Review, v. 50, p. 203-212, 2015.

PIZELLA, D. G.; SOUZA, M. P. D. Strategic Environmental Assessment for watershed management plans. Engenharia Sanitária e Ambiental, v. 18, n. 3, p. 243-252, 2013.

POPE, J.; et al. Are current effectiveness criteria fit for purpose? Using a controversial Strategic 
Assessment as a test case. Environmental Impact Assessment Review, v. 70, p. 34-44, 2018.

RAMOS, Tomás B. et al. Strategic Environmental Assessment in higher education: Portuguese and Brazilian cases. Journal of Cleaner Production, v. 106, p. 222-228, 2015.

RIZZO, H. B.; GALLARDO, A. L. C. F.; MORETTO, E. M. Strategic environmental assessment and transportation sector planning in the state of São Paulo. Engenharia Sanitária e Ambiental, n. AHEAD, p. 0-0, 2017.

SÁNCHEZ, L. E. Por que não avança a avaliação ambiental estratégica no Brasil? Estudos Avançados, v. 31, n. 89, p. 167-183, 2017.

SÁNCHEZ, L. E.; MORRISON-SAUNDERS, A. Teaching impact assessment: results of an international survey. Impact Assessment and project appraisal, v. 28 n. 3, p. 245-250, 2010.

SÁNCHEZ, L. E.; SILVA-SÁNCHEZ, S. S. Tiering Strategic Environmental Assessment and Project Environmental Impact Assessment in Highway Planning in São Paulo, Brazil. Environmental Impact Assessment Review , v. 28, n. 7, p. 515-522, 2008.

SANGUINETTO, E. Avaliação de Impactos Ambientais (AIA), Avaliação Ambiental Estratégica (AAE) e Sustentabilidade em Minas Gerais. Labor E Engenho, v. 5, n. 3, p. 100-120, 2011.

SANTI, A. D.; et al. O processo participativo na Avaliação Ambiental Estratégica (AAE): aplicação de critérios de participação em relatórios de AAE da Bolívia. Desenvolvimento e Meio Ambiente, v.5, p. 42- 55, 2018.

SANTOS, R. F; TEIXEIRA, L. P. The blue amazon management system as na instrument to contribute to the Strategic Environmental Assessment of plans, programs and projects in government sectors in Brazil. Sistemas \& Gestão, v. 12, n. 3, p. 316-327, 2017.

SANTOS, S. M. D.; SOUZA, M. P. D. Analysis of the potential contributions of the Strategic Environmental Assessment to the Brazilian Energy Plan. Engenharia Sanitária e Ambiental, v. 6, n. 4, p. 369-378, 2011.

SECRON, M. B.; et al. Proposal of a hydric index to support industrial site location decisionmaking applying a fuzzy multi-attribute methodology. Ecological indicators, v. 83, p. 427-440, 2017.

SEHNEM, S.; et al. Recursos organizacionais em frigoríficos e sua relação com a implantação de estratégias voltadas à sustentabilidade ambiental: $\mathrm{O}$ caso do Grupo Marfrig Alimentos SA. Revista Brasileira de Gestão de Negócios, v. 14, n. 43, p. 193-215, 2012.

SILVA, A. W. L.; et al. A framework for governance of sustainability indicator systems in Strategic Environmental Assessment processes. Journal of Environmental Assessment Policy and Management, v. 21 n. 01, 1950007, 2019.

SILVA, A. W. L.; SELIG, P. M. Transdisciplinarity-oriented Strategic Environmental Assessment. Engenharia Sanitária e Ambiental, v. 20, n. 2, p.165-174, 2015. 
SILVA, A. W. L.; SELIG, P. M.; MORALES, A. B. T. Indicadores de sustentabilidade em processos de avaliação ambiental estratégica. Ambiente $\boldsymbol{\&}$ Sociedade, v. 15, n. 3, p. 75-96, 2012.

SILVA, A. W. L.; SELIG, P. M.; VAN BELLEN, H. M. Use of sustainability indicators in Strategic Environmental Assessment processes conducted in Brazil. Journal of Environmental Assessment Policy and Management, v. 16, n. 02, p. 1450008, 2014.

SILVA, G. D. P.; et al. Environmental licensing and energy policy regulating utilityscale solar photovoltaic installations in Brazil: status and future perspectives. Impact Assessment and Project Appraisal, p. 1-13, 2019.

SILVA, H. V. O.; et al. Key recent experiences in the application of SEA in Brazil. Journal of Environmental Assessment Policy and Management, v. 16, n. 02, 1450009, 2014.

SIQUEIRA-GAY, J.; SÁNCHEZ, L. E. Mainstreaming environmental issues into housing plans: The approach of strategic environmental assessment. Environmental Impact Assessment Review, v. 77, p. 145-153, 2019.

TETLOW, M.; HANUSCH, M. Strategic Environmental Assessment: the state of the art. Impact Assessment and Project Appraisal, v. 30, n. 1, p. 15-24, 2012.

TSHIBANGU, G. M. An Analysis of Strategic Environmental Assessment Legislation and Regulations in African Countries. Journal of Environmental Assessment Policy and Management, v. 20 n. 01, 1850002, 2018.

TSHIBANGU, G. M.; MONTAÑO, M. Energy related strategic environmental assessment applied by multilateral development agencies - An analysis based on good practice criteria. Environmental Impact Assessment Review, v. 61, p.27-37, 2016.

TSHIBANGU, G. M.; MONTAÑN, M. Outcomes and contextual aspects of strategic environmental assessment in a non-mandatory context: the case of Brazil. Impact Assessment and Project Appraisal, v. 37, n. 3-4, p. 334-343, 2019.

TURCO, L. E. G.; GALlARDO, A. L. C. F. Avaliação de Impacto Ambiental e Avaliação Ambiental Estratégica: há evidências de tiering no planejamento de transportes paulista? Gestão \& Regionalidade, v. 34, n. 101, 2018.

VIEIRA, M. C. M.; et al. Plano de gestão integrada de resíduos sólidos de São Paulo na perspectiva da avaliação ambiental estratégica. urbe. Revista Brasileira de Gestão Urbana, v. 11, 2019.

VILARDO, C; LA ROVERE, E. L. Multi-project environmental impact assessment: insights from offshore oil and gas development in Brazil. Impact Assessment and Project Appraisal, v. 36, n. 4, p. 358-370, 2018.

WESTIN, F. F.; SANTOS, M. A.; MARTINS, I. D. Hydropower expansion and analysis of the use of strategic and integrated environmental assessment tools in Brazil. Renewable and Sustainable Energy Reviews, v. 37, p. 750-761, 2014. 
WOOD, C.; DJEDDOUR, M. Environmental assessment of policies, plans and programmes. Interim report to the Commission of European Communities. Contract, n. B6617-571, p. 572 89, 1989.

ZIONI, S.; DE FREITAS, S. R. Environmental Aspects in the National Plan for Logistics and Transportation in Brazil. Desenvolvimento e Meio Ambiente, v.35, p. 195-208, 2015.

Submitted on: 07/02/2019

Accepted on: 15/08/2021

2021;24e:00223

\author{
Amarilis Lucia Casteli Figueiredo Gallardo \\ $\varangle$ amarilislcfgallardo@gmail.com \\ ORCiD: https://orcid.org/0000-0002-5169-997X
}

Débora Mendonça Monteiro Machado

$\square$ debora87mm@hotmail.com

ORCiD: https://orcid.org/0000-0001-7797-3247 


\section{Cláudia Terezinha Kniess}

『kniesscl@gmail.com

ORCiD: https://orcid.org/0000-0002-1961-2037

How to cite: GALLARDO, A.L.C.F.; MACHADO, D.M.M.; KNIESS, C.T. Strategic Environmental Assessment in Brazilian Academic Research. Ambiente \& Sociedade. São Paulo, v. 24, p. 1-25, 2021.

estáidentificado, estábajounaLicenciaCreativeCommons. 
Amarilis Lucia Casteli Figueiredo Gallardo

凹amarilislcfgallardo@gmail.com

ORCiD: https://orcid.org/0000-0002-5169-997X

\section{Débora Mendonça Monteiro Machado}

凹debora87mm@hotmail.com

ORCiD: https://orcid.org/0000-0001-7797-3247

\section{Cláudia Terezinha Kniess}

\kniesscl@gmail.com

ORCiD: https://orcid.org/0000-0002-1961-2037

How to cite: GALLARDO, A.L.C.F.; MACHADO, D.M.M.; KNIESS, C.T. Strategic Environmental Assessment in Brazilian Academic Research. Ambiente \& Sociedade. São Paulo, v. 24, p. 1-26, 2021. 


\title{
Avaliação Ambiental Estratégica na Pesquisa Acadêmica Brasileira
}

\author{
Amarilis Lucia Casteli Figueiredo Gallardo \\ Débora Mendonça Monteiro Machado \\ Cláudia Terezinha Kniess
}

São Paulo. Vol. 24, 2021

Artigo Original
Resumo: A Avaliação Ambiental Estratégica (AAE) é instrumento para integração da variável ambiental no planejamento, com crescente destaque na pesquisa de avaliação de impacto no mundo. Mesmo não mandatória no Brasil, há aplicações e iniciativas de formalização no quadro legal ambiental. O objetivo deste artigo é explorar a pesquisa acadêmica brasileira sobre AAE por meio de análise quantitativa e qualitativa de artigos, teses e dissertações. Os resultados revelam que a pesquisa local está representada, desde 2000 a 2020, por 75 dissertações e teses de 20 universidades e, desde 2005 a 2020, por 61 artigos de 114 autores, publicados em 30 periódicos indexados. A pesquisa, embora em fase inicial de desenvolvimento, caracteriza-se por: um diagnóstico amplo da aplicação local da AAE; contribuições para um sistema brasileiro; pouca discussão metodológica; e análise da qualidade dos relatórios brasileiros. Recomenda-se que as pesquisas futuras estejam direcionadas a fomentar e construir um marco legal de AAE para o planejamento brasileiro.

Palavras-chave: Avaliação Ambiental Estratégica, pesquisa acadêmica, planejamento setorial e territorial, Brasil.

Como citar: GALLARDO, A.L.C.F.; MACHADO, D.M.M.; KNIESS, C.T. Avaliação Ambiental Estratégica na Pesquisa Acadêmica Brasileira. . Ambiente \& Sociedade. São Paulo, v. 24, p. 1-25, 2021. 


\title{
Evaluación Ambiental Estratégica en la Investigación Académica Brasileña
}

\author{
Amarilis Lucia Casteli Figueiredo Gallardo \\ Débora Mendonça Monteiro Machado \\ Cláudia Terezinha Kniess
}

São Paulo. Vol. 24, 2021

Resumen: La Evaluación Ambiental Estratégica (EAA) es un instru-

Artículo original mento para integrar la variable ambiental en la planificación estratégica, con un énfasis creciente en la investigación mundial acerca de evaluación de impacto. Aunque no es obligatorio en Brasil, existen aplicaciones e iniciativas de formalización. El objetivo es explorar la investigación académica brasileña sobre EAA a través del análisis cuantitativo y cualitativo de artículos, tesis y disertaciones. Los resultados muestran que la investigación está representada, desde 2000 a 2020, por 75 disertaciones y tesis de 20 universidades y, desde 2005 a 2020, por 61 artículos de 114 autores, publicados en 30 revistas indexadas. La investigación, aunque en etapa temprana de desarrollo, cubre un diagnóstico amplio de la aplicación de la EAA; contribuciones a un sistema brasileño; poca discusión metodológica; y análisis de la calidad de los reportes brasileños. Se recomienda que las investigaciones futuras estén orientadas a impulsar y construir un marco legal local para la EAA.

Palabras-clave: Evaluación Ambiental Estratégica; investigación académica; planificación sectorial y territorial; Brasil.

Como citar: GALLARDO, A.L.C.F.; MACHADO, D.M.M.; KNIESS, C.T. Evaluación Ambiental Estratégica en la Investigación Académica Brasileña. Ambiente \& Sociedade. São Paulo, v. 24, p. 1-25, 2021.

DOI: http://dx.doi.org/10.1590/1809-4422asoc20200022r3vu2021L5AO 